Brock, R. (1957) Functional obstruction to left ventricle. Guy's Hospital Report, 106, 221.

Ellis, F.H., Jr, ONgley, P.A. \& Kirklin, J.W. (1962) Results of surgical treatment for congenital aortic stenosis. Circulation, 25, 29.

GoRDON, O.S. (1962) The surgical management of congenital supravalvar, valvar and subvalvar aortic stensosis using deep hypothermia. Journal of Thoracic and Cardiovascular Surgery, 43, 141.
Hurst, J.W., Jr \& Logue, R.B. (1966) The Heart, Arteries and Veins, p. 579. McGraw-Hill, New York.

Nanda, N.C., Gramiak, R., Shah, P.M., Stewart, S. \& DE WEESE, J.A. (1974) Echocardiography in the diagnosis of idiopathic hypertrophic subaortic stenosis co-existing with aortic valve disease. Circulation, 50, 752.

Parker, D.P., Kaplan, M.A. \& Connolly, J.E. (1969) Coexistent aortic valvar and functional hypertrophic subaortic stenosis. American Journal of Cardiology, 24, 307.

\title{
Hypocalcaemia and convulsions
}

\author{
M. M. GUPTA \\ M.D. \\ D. N. GROVER \\ M.D.
}

\section{Department of Medicine, Armed Forces Medical College, Pune-1, India}

\begin{abstract}
Summary
Hypocalcaemia may manifest with tetany, convulsions and even status epilepticus. Recognition of underlying hypocalcaemia in convulsions is mandatory because the fits may not be adequately controlled by anti-convulsant drugs which may also aggravate hypocalcaemia. Vitamin $D$, by relieving hypocalcaemia, reduces the frequency of convulsions and may even eliminate them.
\end{abstract}

\section{Introduction}

A sustained fall in the physiologically active ionized calcium of the plasma is due to a failure of the homeostatic mechanisms regulating the plasma calcium within a narrow normal range. Such homeostatic mechanisms involve the integrated actions of parathyroid hormone, vitamin $\mathbf{D}$ and possibly calcitonin. Besides parathyroid insufficiency and dietary deficiency of vitamin $\mathrm{D}$, magnesium deficiency, anticonvulsant drugs, chronic renal failure, and steatorrhoea are the other common causes of hypocalcaemia. Hypocalcaemia is a well recognized cause of tetany and convulsions. Anti-convulsant drugs may be advised for such patients which do not control the seizures and may aggravate hypocalcaemia, setting up a vicious cycle necessitating increasing doses of anticonvulsant drugs.

These disturbances of the calcium metabolism are illustrated in three cases now described.

\section{Case reports}

Case 1

A 40-year-old male presented with what was diagnosed as a multinodular goitre. This was re- moved and histopathology revealed follicular carcinoma. Total thyroidectomy was undertaken 3 months later and replacement therapy thyroxine $0.3 \mathrm{mg}$ /day was given. The patient developed paraesthesiae in all four limbs within a week of surgery, for which he was given calcium gluconate tablets orally. Fifteen months after thyroidectomy he complained of failing vision which was attributed to presbyopia but later proved to be a cataract which was successfully removed. The patient had a fit resembling grand mal seizure 2 months later. Since then he has had several convulsive fits which have been treated with phenobarbital. Bilateral papilloedema was noticed 2 months after the first seizure. There was generalized constriction of fields of vision. Electroencephalogram revealed slow waves from the frontal areas. X-ray of the skull, ventriculography and carotid angiography were normal, as was the cerebrospinal fluid. Plasma calcium on two occasions was recorded as $9 \mathrm{mg} / 100 \mathrm{ml}(2 \cdot 25$ $\mathrm{mmol} / \mathrm{l})$ and $7 \mathrm{mg} / 100 \mathrm{ml}(1.75 \mathrm{mmol} / \mathrm{l})$ respectively. Possibility of space occupying lesion in brain due to secondaries from thyroid carcinoma was excluded and the patient was treated with phenobarbital (150 $\mathrm{mg} /$ day). The patient had more fits while on phenobarbital; these were partly controlled with intravenous calcium gluconate. The patient was referred to the authors 23 months after thyroidectomy. He was depressed and worried because he was to lose his job in view of uncontrolled epilepsy. Chvostek's and Trousseau's signs were positive. There was bilateral cataract. The plasma calcium was 6.6 and $7.0 \mathrm{mg} /$ $100 \mathrm{ml}(165$ and $1.75 \mathrm{mmol} / \mathrm{l})$ on two occasions (sp. gr. 1027); plasma inorganic phosphorus was $4.5 \mathrm{mg} / 100$ 


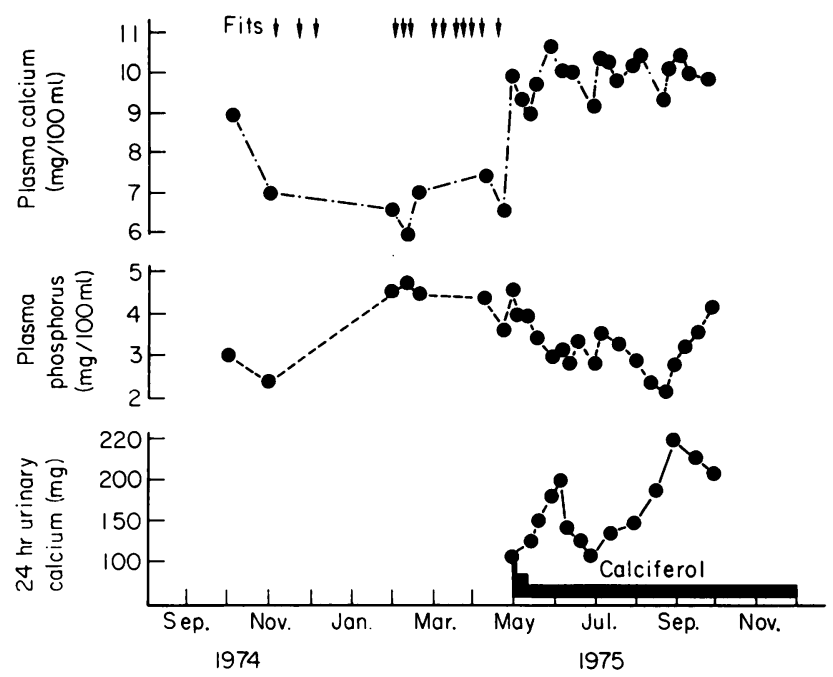

FIG. 1. Case 1. Follow-up in post-thyroidectomy hypoparathyroidism. Treatment with calciferol resulted in elimination of epileptic seizures.

$\mathrm{ml}(1.45 \mathrm{mmol} / \mathrm{l})$ and alkaline phosphatase $8.5 \mathrm{KAu} . /$ $100 \mathrm{ml}$. Fasting blood sugar was $90 \mathrm{mg} / 100 \mathrm{ml}(5 \cdot 0$ $\mathrm{mmol} / \mathrm{l})$, serum creatinine $1.0 \mathrm{mg} / 100 \mathrm{ml}(88.4$ $\mu \mathrm{mol} / \mathrm{l})$; liver function tests, urea and electolytes were normal. Serum PBI was $7.5 \mu \mathrm{g} / 100 \mathrm{ml}$ and the serum magnesium was $1.5 \mathrm{mmol} / \mathrm{l}$. Urinary calcium was $119 \mathrm{mg} / 24 \mathrm{hr}$. $(2.975 \mathrm{mmol} / 24 \mathrm{hr}$.).

The diagnosis was that of postoperative hypoparathyroidism. Vitamin $D_{2}$ was given orally $5 \mathrm{mg}$ on the first day, $2.5 \mathrm{mg}$ for the next 7 days and then a daily maintenance dose of $1.25 \mathrm{mg}$. Calcium gluconate, $20 \mathrm{ml}$ of $10 \%$, was given intravenously on the first day and then orally 3 tablets t.i.d. $(450 \mathrm{mg}$ of calcium) together with thyroxine $0.2 \mathrm{mg} /$ day. The results of plasma calcium, phosphorus, and 24-hr urinary excretion of calcium are shown in Fig. 1. After taking vitamin D the patient had no more fits or convulsions.

\section{Case 2}

A 35-year-old woman was admitted complaining of increasing bony pains over pelvis, femur, ribs and sternum and inability to stand and walk for the past 14 months. There was no history suggestive of steatorrhoea, renal failure or epilepsy. She was anaemic and had severe bony tenderness over pelvis and chest. Chvostek's and Trousseau's signs were negative. BP was $150 / 90 \mathrm{mmHg}$. She had gross proximal muscular weakness.

Investigations. Haemoglobin was $10.5 \mathrm{~g} / 100 \mathrm{ml}$ and ESR was $50 \mathrm{~mm}$ in the first hour. Total and differential counts of white blood cells were normal. Midstream urine contained a trace of protein and a few pus cells and sp. gr. was 1016. Urine culture revealed
Escherichia coli infection. Five consecutive samples of urine had a pH of $6 \cdot 0,6 \cdot 2,6 \cdot 3,6.6,6 \cdot 0$ respectively. The 24-hr urinary calcium was $40 \mathrm{mg}$. (1 mmol.). Plasma calcium on two occasions was $7.8 \mathrm{mg} / 100 \mathrm{ml}(1.95 \mathrm{mmol} / \mathrm{l})$ and $7.6 \mathrm{mg} / 100 \mathrm{ml}$ $(1.90 \mathrm{mmol} / \mathrm{l})$ (sp. gr. 1027 in each instance). Plasma inorganic phosphorus was $2.3 \mathrm{mg} / 100 \mathrm{ml}(0.74 \mathrm{mmol} / 1$ and alkaline phosphatase was $42 \mathrm{KAu}$. $/ 100 \mathrm{ml}$. Blood urea was $45 \mathrm{mg} / 100 \mathrm{ml}(7.47 \mathrm{mmol} / \mathrm{l})$; serum creatinine, $0.6 \mathrm{mg} / 100 \mathrm{ml}(53.04 \mu \mathrm{mol} / \mathrm{l})$; total proteins, $7 \cdot 2 \mathrm{~g} / 100 \mathrm{ml}(72 \mathrm{~g} / \mathrm{l}$ ) (albumin, $4 \cdot 2 \mathrm{~g} / 100 \mathrm{ml}$ $(42 \mathrm{~g} / \mathrm{l})$; globulins, $3.0 \mathrm{~g} / 100 \mathrm{ml}(30 \mathrm{~g} / \mathrm{l}))$; plasma sodium, $138 \mathrm{mg} / 100 \mathrm{ml}$, potassium $5.0 \mathrm{mg} / 100 \mathrm{ml}$, chlorides $118 \mathrm{mg} / 100 \mathrm{ml}$ and $\mathrm{HCO}_{3} 18 \mathrm{mg} / 100 \mathrm{ml}$. Radiological survey of the skeleton revealed pseudofractures of both pelvic rami. There was no renal or pancreatic calcification. Faecal fat was $5 \mathrm{~g} / 24 \mathrm{hr}$ and D-xylose test was normal. Barium meal followthrough did not reveal any abnormality.

A diagnosis of osteomalacia was made; pyelonephritis and renal tubular acidosis were considered as possibilities. The patient was treated with ampicillin for $E$. coli infection, $\mathbf{4 0} \mathrm{g}$ protein diet, sodium bicarbonate $1 \mathrm{~g}$ b.d. and calcium gluconate tablets (equivalent to $450 \mathrm{mg}$ calcium). The patient had an epileptic seizure 13 days after admission; this was controlled with $10 \mathrm{ml}$ of $10 \%$ calcium gluconate intravenously. Vitamin $D_{2}(5 \mathrm{mg}$ i.m./day) was started immediately. The biochemical data are shown in Fig. 2. The patient developed further fits 2 days later and then became deeply comatose. Status epilepticus was diagnosed and she was given i.v. diazepam, $10 \mathrm{mg}$. i.v. calcium gluconate, $20 \mathrm{ml} / 6 \mathrm{hr}$. as well as aluminium hydroxide orally. Acidosis and 




Fig. 2. A progress chart for case 2.
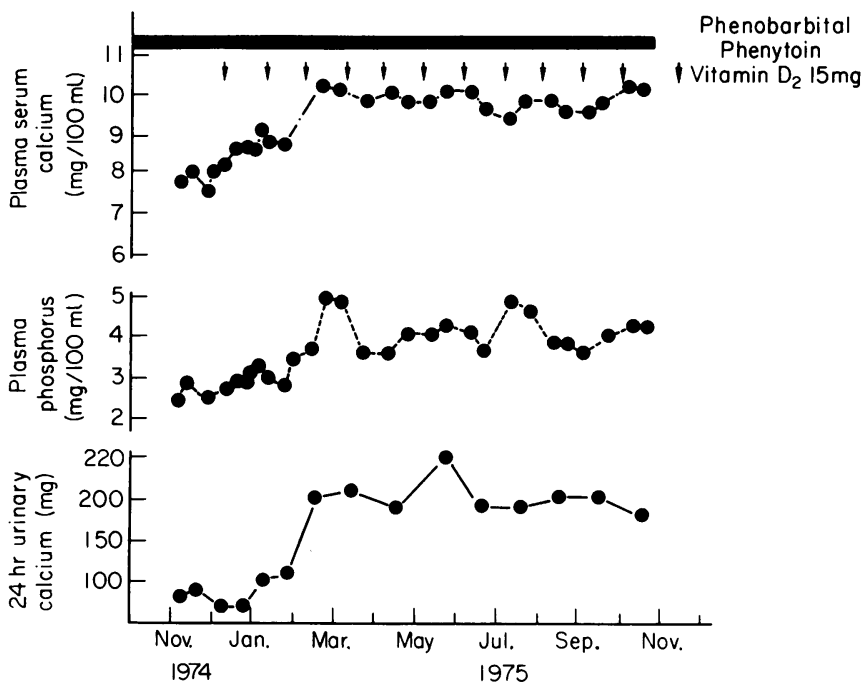

Fig. 3. Follow-up for case 3.

hypokalaemia were treated with i.v. sodium bicarbonate $(9 \mathrm{mmol} / 6 \mathrm{hr})$ and potassium chloride (20 $\mathrm{mmol} / 12 \mathrm{hr}$ ). She did not recover and died 15 days after admission.

\section{Case 3}

A young man, whose grand mal epilepsy had been diagnosed at the age of 18 months, presented, at the age of 22 years, when he had been treated for this with $300 \mathrm{mg}$ of phenytoin and $60 \mathrm{mg}$ of phenobarbital for 15 years. He was complaining of increasing seizures over the past 4 months. On examination, he was of average height and weight, with no evidence of past rickets. Neurological examination did not reveal any abnormality. The fundi were normal. Routine investigations revealed plasma calcium $7.8 \mathrm{mg} / 100 \mathrm{ml} \mathrm{(1.95} \mathrm{mmol} / \mathrm{l})$ (sp. gr. 1027), serum inorganic phosphorus $2.5 \mathrm{mg} / 100 \mathrm{ml}$ and alkaline phosphatase $7.0 \mathrm{KAu} . / 100 \mathrm{ml}$. Hypocalcaemia was further confirmed on three subsequent occasions. Urinary calcium was $100 \mathrm{mg} / 24 \mathrm{hr}$. $(2.5 \mathrm{mmol} / 24 \mathrm{hr}$.). Electrolytes and urea were within 
normal limits. X-rays of skull, pelvis and knees did not reveal any abnormality. Hypocalcaemia was considered secondary to anti-convulsant therapy. $\mathrm{He}$ was treated with i.m. vitamin $D_{2} 15 \mathrm{mg}$ once a month while the anti-convulsant drugs were continued in the same doses. Plasma calcium gradually returned to normal. At the time of writing he has had no seizure for 6 months. The progress of the case is shown in Fig. 3.

\section{Discussion}

Accidental damage to the parathyroids during a thyroid operation remains the commonest cause of hypoparathyroidism. Resulting hypocalcaemia can produce epilepsy and anticonvulsants do not prevent them completely (Grant, 1953). Abnormalities in electroencephalograms have been reported but these revert back to normal after normocalcaemia has been attained (Fourman et al., 1963). When the seizures are associated with bilateral papilloedema a mistaken diagnosis of brain tumour may be made (Barr, MacBryde and Sanders, 1938), as in case 1. The seizures were not controlled by anticonvulsants but were eliminated by calciferol. If epilepsy persists after achieving normocalcaemia, anticonvulsants may then be added carefully to the treatment. Cataract, as seen in case 1, is related to hypocalcaemia rather than to hypoparathyroidism because cataract has also been reported in osteomalacia (Vaishnava, 1975).

Hypocalcaemia is a significant biochemical finding in cases of rickets and osteomalacia. While hypocalcaemic tetany is fairly common in florid rickets, the presence of convulsions has not been particularly stressed in reports of osteomalacia in Western literature (Holmes et al., 1973; Mankin, 1974; Fourman and Royer, 1968; Albright and Reifenstein 1948). In a recent review of 593 patients with osteomalacia in Northern India, Vaishnava (1975) reported convulsions as the presenting feature in $1.34 \%$ of cases. Case 2 in the present report presented with typical features of osteomalacia. Renal tubular acidosis and chronic renal insufficiency could have contributed to its aetiology. She developed convulsions and unfortunately succumbed to status epilepticus in spite of vigorous calcium therapy. In chronic renal failure, vitamin $D$ deficiency is related to a reduced synthesis of 1 , 25-dihydroxycholecalciferol in the kidneys, and hypocalcaemia ensues because of ineffectiveness of parathormone in the absolute deficiency of 1,25dihydroxycholecalciferol (Woodhouse, 1974). Tetany and convulsions are rare in hypocalcaemia of chronic renal failure owing to associated metabolic acidosis, but can be precipitated by giving alkalis without calcium and vitamin $D$.

About $22 \%$ of epileptic patients on long-term anticonvulsants develop hypocalcaemia (Richens and Rowe, 1970). Dent et al. (1970) suggested that hypocalcaemia (and rickets in some of those cases) was due to an increased conversion of vitamin $D$ into inactive metabolites instead of active 25-hydroxycholecalciferol in the liver. Biassani (1971) reported epileptic crisis from hypocalcaemia in a patient treated with anticonvulsant drugs. In a recent pilot study in Southern India, Nair (1975) has reported the efficacy of vitamin $D$ in reducing the frequency of epileptic fits. However, his study was not supported by biochemical data. All patients with epilepsy do not require vitamin $D$ but should have a periodic check-up of their plasma calcium, phosphorus and alkaline phosphatase. Case 3 was treated with vitamin $\mathbf{D}_{2}$ after hypocalcaemia had been confirmed but it was 2 months before his plasma calcium returned to normal.

\section{Acknowledgment}

We thank Professor C. E. Dent, FRS, of University College Medical School, London, for his advice in the preparation of this article.

\section{References}

Albright, F. \& Reifenstein, C.E. (1948) The Parathyroid Glands ana Metabolic Bone Disease, pp. 205-262. Williams and Wilkins Co., Baltimore.

BarR, D.P., MacBryde, C.M. \& SANders, T.E. (1938) Tetany with increased intracranial pressure and papilledema. Transactions of the Association of American Physicians, 53, 227.

Biassani, G.C. (1971) Tetanic crisis in a patient treated with anticonvulsants. Minerva paediatrica, 23, 1798.

Dent, C.E., Richens, A., Rowe, D.J.F. \& Stamp, T.C.B. (1970) Osteomalacia with long term anticonvulsant therapy in epilepsy. British Medical Journal, 4, 69.

Fourman, P., Davis, R.H., Jones, K.H., Morgan, D.B. \& Sмith, J.W.G. (1963) Parathyroid insufficiency. British Journal of Surgery, 50, 608.

Fourman, P. \& Royer, P. (1968) Calcium Metabolism and the Bones, pp. 271-299. Blackwell Scientific Publications, Oxford.

GraNT, D.K. (1953) Papilloedema and fits in hypoparathyroidism with a report of three cases. Quarterly Journal of Medicine, 22, 243.

Holmes, A.M., Enoch, B.A., TAylor, J.L. \& Jones, M.E. (1973) Occult rickets and osteomalacia amongst the Asian immigrant population. Quarterly Journal of Medicine, 42, 125.

Mankin, H.J. (1974) Rickets, osteomalacia and renal osteodystrophy. Journal of Bone and Joint Surgery, 56, 101.

NAIR, G.K. (1975) A pilot study of oral vitamin $D_{2}$ in epileptics on anticonvulsants. Journal of the Association of Physicians of India, 23, 267.

Richens, A. \& Rowe, D.J.F. (1970) Disturbance of calcium metabolism of anticonvulsant drugs. British Medical Journal, 4, 73.

Vaishnava, H. (1975) Vitamin D deficiency osteomalacia in Northern India. Journal of the Association of Physicians of India, 23, 477.

WoodHouse, N.J.Y. (1974) Hypocalcaemia and hypoparathyroidism. Clinics in Endocrinology and Metabolism, 3, 323. 